\title{
REDACTIONEEL
}

\section{Criminele groepen: een inleiding}

\author{
Robby Roks, Arjan Blokland \& Frank Weerman
}

Crimineel en deviant gedrag is vaak een collectieve aangelegenheid. Daarom krijgen criminele groepen traditioneel veel aandacht in criminologisch onderzoek. Er blijft echter in de wetenschappelijke literatuur discussie over wat er wordt bedoeld met de term 'criminele groep' of wanneer er sprake is van een specifieke criminele groep zoals een gang. In deze bijdrage wordt een aantal recente ontwikkelingen belicht die er op wijzen dat de grenzen tussen verschillende criminele groepen tegenwoordig minder duidelijk afgebakend zijn dan door zowel binnen- als buitenstaanders wordt verondersteld. Ook de structuur en dynamiek van criminele groepen lijkt te veranderen, mede als gevolg van de opkomst van social media en smartphones. Hoe deze (nieuwe) criminele groepen ontstaan, functioneren, zich ontwikkelen, en welke rol de verschillende groepen spelen bij criminele activiteiten blijven daarmee relevante criminologische vragen voor toekomstig onderzoek.

\section{Inleiding}

Ingegeven door ontwikkelingen op theoretisch en methodologisch vlak wijdde het Tijdschrift voor Criminologie vijftien jaar geleden een themanummer aan 'criminele groepen en samenwerkingsverbanden'. Het redactioneel begon destijds met de opmerking dat 'de mens een sociaal wezen is en plegers van delicten hierop geen uitzondering vormen' (Weerman \& Kleemans, 2002, 114). Van oudsher hebben criminologische studies daarom aandacht gehad voor de groepsdimensie van criminele activiteiten of vormen van afwijkend gedrag. Weerman en Kleemans constateerden destijds dat de beeldvorming rondom criminele groepen en samenwerkingsverbanden aan het schuiven was en dat traditionele beelden van een piramidaal georganiseerde maffia en van klassieke hiërarchische jeugdbendes in toenemende mate werden genuanceerd door wetenschappelijk onderzoek.

Vijftien jaar na dato blijkt de term 'criminele groep' nog even complex, zo niet complexer. Nieuwe groepen die worden geassocieerd met wetsovertreding en onveiligheid verschijnen in het maatschappelijk discours, zoals outlawbikers, rondtrekkende dadergroepen uit Oost-Europa en radicale en terroristische bewegingen zoals Islamitische Staat. Tegelijkertijd veranderen de structuur en dynamiek van groepen als gevolg van de opkomst van social media en smartphones. Er ontstaan ook hybride groepen, die kenmerken hebben van voorheen verschillende categorieën, zoals groepen voetbalsupporters waarbinnen leden zich bezighouden met georganiseerde drugshandel, en mengvormen tussen 'outlaw motorcycle gangs' en traditionele 'street gangs'. Er is daarnaast een toenemende tendens binnen het veiligheidsbeleid om bepaalde groepen actief te bestrijden, hard aan te 
pakken en in sommige gevallen zelfs te criminaliseren, zoals recent bijvoorbeeld blijkt uit de pogingen van het Openbaar Ministerie om 'outlaw motorcycle gangs' zoals Satudarah MC en Bandidos MC door de rechter te laten verbieden. ${ }^{1}$

Hoe deze groepen in elkaar zitten en welke rol de verschillende groepen nu precies vervullen bij de criminele activiteiten van hun leden blijven daarom nog steeds belangrijke criminologische onderwerpen. Genoeg reden voor de redactie van het Tijdschrift voor Criminologie voor een nieuw themanummer over criminele groepen.

\section{Wat zijn criminele groepen?}

Het huidige themanummer draagt als titel 'Criminele groepen'. Het is echter lang niet altijd duidelijk wat er precies met dit begrip bedoeld wordt, en dat wordt nog eens bemoeilijkt doordat in de praktijk uiteenlopende termen worden gebruikt. Groepen jongeren die, veelal in de stedelijke context, overlast en criminaliteit veroorzaken, worden bijvoorbeeld aangeduid als problematische jeugdgroepen. Rondtrekkende personen uit Midden- en Oost-Europa die zich gezamenlijk schuldig maken aan vermogenscriminaliteit worden aangeduid als 'mobiele bendes'. Outlawbikers maken deel uit van een 'club' of 'gang'. Terroristen zijn actief in 'cellen'. 'Hooligans' is de term die gebruikt wordt voor voetbalsupporters die voor, tijdens of na wedstrijden gezamelijk vernielingen aanrichten en met elkaar of de politie op de vuist gaan. Zelfs de term 'maffia' duikt van tijd tot tijd weer op, zoals recentelijk rondom de zogenaamde 'Mocro maffia' (Laumans \& Schrijver, 2014).

Of en hoe de term 'groep' wordt gebruikt, en hoe onderscheid wordt gemaakt tussen diegenen die wel en diegenen die niet tot de 'groep' behoren, wordt vaak opgelegd door buitenstaanders (Spaaij, 2008). Dat kunnen journalisten zijn en personen uit andere media, politici en bestuurders, maar ook academici en professionals die actief zijn in het veiligheidsbeleid. De afbakening van criminele groepen hangt ook nog eens af van het doel waarmee en de context waarin buitenstaanders de term gebruiken. Daardoor worden het begrip criminele groep, en allerlei synoniemen daarvan, gebruikt voor verschillende soorten collectiviteiten en bestaan er uiteenlopende beelden over deze groepen, die niet overeen hoeven te komen met de werkelijkheid.

Ook 'insiders', zij die zelf deel uitmaken van een groep, maken onderscheid tussen wie wel en wie niet tot de 'groep' behoort. Soms doen zij dit op basis van met buitenstaanders vergelijkbare criteria, andere keren gaan ze uit van het al of niet bestaan van een familieband of kennisrelatie. Maar ook minder tastbare zaken zoals 'groepsidentiteit' spelen een beslissende rol. Betekenisvolle categorieën van de onderzoekspopulatie zelf worden echter vaak buiten beschouwing gelaten, niet alleen in de mediaberichtgeving en het overheidsbeleid, maar ook in veel van het wetenschappelijk onderzoek naar deze groepen. Dat is jammer, want waar de pre-

1 Zie bijvoorbeeld: 'Drie kopstukken Satudarah opgepakt, justitie gaat proberen motorclub te verbieden' (de Volkskrant, 26 september 2017) en 'Een verbod op een motorclub? Het OM doet een nieuwe poging' (de Volkskrant, 2 oktober 2017). 
cieze grenzen liggen van de groep, of zelfs het al of niet bestaan van de groep, kan door buitenstaanders en binnenstaanders heel anders worden ervaren.

Een basaal onderscheid dat we in de criminologie kunnen maken, is dat tussen dadergroepen, netwerken van daders, groepen (clubs of gangs) waarvan daders deel kunnen uitmaken, en subculturen of bewegingen die in meer of mindere mate kunnen leiden tot criminaliteit. Bij dadergroepen gaat het om verbanden van mededaders die eenmalig of meermalen een concreet delict plegen. De modale groepsgrootte is klein: in de meeste gevallen is er sprake van twee, drie of vier samenplegers (Weerman, 2001; Van Mastrigt, 2014). Maar er zijn ook delictsoorten waarbij dadergroepen vaak groter zijn, zoals openbareordeverstoring en vernieling. Ook de rondtrekkende dadergroepen die worden besproken in een van de bijdragen aan dit themanummer zijn relatief groot. Ze kunnen bestaan uit enkele tientallen personen, die in wisselende samenstelling te werk gaan. Het kenmerk van dadergroepen is niet alleen dat groepsleden samen delicten plegen, maar ook dat ze elkaar persoonlijk kennen en in nauw contact met elkaar staan.

Bij netwerken van daders gaat het om plegers van misdrijven die indirect met elkaar in contact staan. Een netwerk omvat meer dan een groep: het is een verzameling van individuen die met elkaar verbonden zijn, zonder dat iedereen elkaar hoeft te kennen. Volgens Kleemans e.a. $(1998,36)$ gaat het om 'een verzameling knooppunten van bijvoorbeeld personen of organisaties en relaties tussen deze knooppunten'. Bij een groep kennen de individuen elkaar doorgaans wel persoonlijk, (her)kennen ze elkaar ook als groepsleden en zijn de onderlinge relaties over het algemeen hechter (Weerman \& Kleemans, 2002, 115-116). Methoden en theorieën over sociale netwerken hebben in de criminologie een grote vlucht genomen en zijn met name toegepast in studies naar georganiseerde misdaad (zie bijvoorbeeld Bruinsma \& Bernasco, 2004; Kleemans \& De Poot, 2008; Morselli, 2013; Morselli \& Boivin, 2017; Papachristos, 2011). Recent is ook sociale netwerkanalyse toegepast op jihadistisch terrorisme (De Bie, 2016).

Een onderscheidend kenmerk van groepen waarvan daders deel kunnen uitmaken, ligt in een gedeelde groepsidentiteit. Bij veel van dergelijke groepen is de groepsidentiteit niet primair geconstrueerd rond crimineel gedrag. Vaker gaat het om een amalgaam van gemeenschappelijke activiteiten en interesses, sociaal-culturele achtergronden en bepaalde gedragscodes en gedeelde waarden. Wanneer leden van dergelijke groepen zich schuldig maken aan crimineel gedrag kan men zich de vraag stellen of, en zo ja, welke rol het groepslidmaatschap gespeeld heeft in de totstandkoming, uitvoering en afwikkeling van dit criminele gedrag. $\mathrm{Bij}$ sommige groepen waarvan daders deel uitmaken, is het plegen van delicten wel een belangrijk onderdeel van de groepsidentiteit of is het criminele gedrag structureel en georganiseerd van aard. Het komt echter zelden voor dat de hele groep zich als collectief crimineel gedraagt.

Tot slot kan met de term 'criminele groep' ook worden gedoeld op subculturen of bewegingen met een meer of minder crimineel karakter. Het meest duidelijk is dat bij extremistische of terroristische bewegingen, zoals Islamitische Staat. Via radicaliseringsprocessen kunnen mensen zich aansluiten bij dit soort 'groepen'. Binnen kleinere eenheden van deze criminele groepen - subgroepen, cellen of jihadistische netwerken - kunnen dan terroristische activiteiten worden onder- 
nomen, maar het is niet zo dat alle deelnemers aan de beweging elkaar persoonlijk kennen, of zelfs maar indirect met elkaar een netwerk vormen. Een ander voorbeeld vormt de subcultuur van 'hooligans'. Daarbinnen worden gewelddadig gedrag en vechten voor de eigen club positief gewaardeerd. Maar het is niet zo dat alle hooligans elkaar persoonlijk kennen of in hetzelfde netwerk zitten - integendeel, binnen de subcultuur bestrijden hooligans van verschillende voetbalclubs elkaar.

\section{Definitiekwesties rond gangs en problematische jeugdgroepen}

Bij groepen waarvan daders deel uit kunnen maken, spelen nog meer definitiekwesties, zoals de vraag wanneer dergelijke groepen kunnen worden aangeduid als 'bende' of 'gang'. Een interessante ontwikkeling in dit verband is dat de term 'gang' de afgelopen jaren vrij geruisloos onderdeel geworden is van het idioom van de overheid en de politie als wordt gesproken over criminaliteit van clubs van motorrijders. Voorheen werd in het geval van outlawbikers in Nederland gesproken over 'motorclubs' en over ' $1 \%-\mathrm{MC}$ 's'. De term '1\%-MC' werd losgelaten nadat 'conformistische motorrijders' klaagden dat ze de dupe werden van het slechte imago dat ontstond rondom motorclubs. In reactie hierop is de minister van Veiligheid en Justitie in 2013 de term 'outlaw motorcycle gangs' gaan gebruiken 'om de overige motorclubs niet te stigmatiseren' (Landelijke Eenheid Politie, 2014, 15). De keuze voor de aanduiding 'OMCG' is ook ingegeven door het idee dat dezelfde term ook door andere landen wordt gebruikt. ${ }^{2}$

Een wezenlijke vraag is echter of deze term voldoende recht doet aan het fenomeen in Nederland. Blokland e.a. (2017) proberen de vraag te beantwoorden waar de Nederlandse outlawbikers geplaatst moeten worden op het door Barker (2014) beschreven club-gangcontinuüm. De auteurs maken gebruik van de afkorting OMCG, maar geven expliciet aan te spreken over clubs en niet over gangs. Hun analyse van 601 criminele carrières toont een grote diversiteit tussen de verschillende OMCG's in Nederland. De auteurs concluderen om die reden dat de vraag of de OMCG's in Nederland gekarakteriseerd moeten worden als clubs, criminele organisaties of gangs wellicht niet de meest relevante vraag is. Om beter zicht te krijgen op de criminele betrokkenheid van OMCG's zou gekeken moeten worden op het niveau van verschillende clubs, chapters of cliques van leden.

Het recente gebruik van de term 'gang' voor outlawbikers is opmerkelijk te noemen omdat er in Nederland lange tijd een zekere terughoudendheid viel waar te nemen rondom het benoemen van groepen als 'gang', in het bijzonder eind jaren tachig rondom groepen jongeren die in uiterlijke zin sterk deden denken aan de stereotiepe Amerikaanse voorbeelden van zwarte gangs (Van Gemert, 1995; 1998; 2012). In Nederland pleitte Van Gemert (1998) toen voor precisering rond het gebruik van het woord 'gang'. Sterker nog: hij meende dat, vanwege de verwarrende associaties die het begrip oproept met Amerikaanse toestanden en praktijken, de term in het geheel niet gebruikt moest worden wanneer verwezen 
werd naar de Nederlandse context. Dit laatste ondanks dat jongeren die lid waren van deze Nederlandse Crips en Bloods zichzelf graag aanduidden als 'gangsta' en hun groep als 'gang', juist vanwege de aantrekkingskracht en de mythes waarmee dit begrip omgeven is (Van Hellemont, 2015). Het gebruik van deze termen betekent overigens niet noodzakelijkerwijs dat deze jongeren zichzelf, of elkaar, ook beschouwen als onderdeel van een afgebakende 'gang' of criminele groep. Deze terminologie geeft eerder uitdrukking aan het beeld, het imago, de reputatie en de identiteit die zij willen overbrengen. Het zijn, met andere woorden, kwalificaties die aangeven hoe deze groepen, of de individuen die hier onderdeel van uitmaken, gezien willen worden (Roks, 2016, 284).

In overheidspublicaties over dit onderwerp in Nederland wordt voornamelijk gesproken over (problematische) jeugdgroepen. Een bepalende rol daarin was weggelegd voor de zogenaamde 'shortlistmethodiek', op de werkvloer door professionals veelal aangeduid als de 'Beke-methodiek'. ${ }^{3}$ Deze methode hield in dat binnen de politiekorpsen wijkagenten en portefeuillehouders jeugd vragenlijsten invulden over de in hun gebied gesignaleerde jeugdgroepen die zorgden voor overlast en criminaliteit. Op basis van deze 'shortlistmethodiek' werd in politiekorpsen en later in heel Nederland een jaarlijkse raming gedaan van de hoeveelheid hinderlijke, overlastgevende en criminele jeugdgroepen in Nederland. De aanduiding 'gang' werd in deze methodiek niet gebruikt, maar kon gelezen worden in de zogenaamde 'plus'-varianten van de criminele jeugdgroepen: de straaten de jeugdbende (Beke e.a., 2000, 125-126). Vanwege de strikte criteria (hecht georganiseerd en/of gesloten en hiërarchisch) werd er echter maar beperkt melding gemaakt van het bestaan van zulke 'plusvarianten', en de kwalificaties straaten jeugdbendes leken zelfs in het geheel verdwenen uit de laatste overzichten van problematische jeugdgroepen in Nederland (Ferwerda \& Van Ham, 2015; 2017). Tegenwoordig wordt vanuit de overheid niet meer gebruik gemaakt van de 'shortlistmethodiek' om problematische jeugdgroepen in beeld te brengen, maar zijn een 'groepsscan' en een handreiking ontwikkeld voor de duiding van problematische jeugdgroepen. Die moeten leiden tot een meer genuanceerd en dynamisch beeld van groepen in een bepaald gebied (Ferwerda \& Van Wijk, 2015; Van Ham \& Ferwerda, 2017). Over bendes of 'gangs' wordt nu niet meer gesproken en ook de driedeling in hinderlijk, overlastgevend en crimineel is losgelaten.

Binnen het 'Eurogang'-programma, een netwerk van internationale wetenschappers, is geprobeerd overeenstemming te bereiken over de omschrijving van gangs of problematische jeugdgroepen. Deze inspanningen hebben geresulteerd in een zogenaamde consensusdefinitie, waarbij een 'street gang' of problematische jeugdgroep volgens deze definitie verwijst naar 'any durable, street-oriented youth group whose involvement in illegal activity is part of their group identity' (Van Gemert e.a., 2008, 5; Weerman e.a., 2009). In deze consensusdefinitie dient het overtreden van de wet dus een integraal onderdeel uit te maken van de groepsidentiteit. Daarmee lijkt voorlopig een status quo bereikt in de welhaast

3 Het was echter niet onderzoeksbureau Beke, maar Gruter e.a. (1996) die op basis van het delictgedrag van problematische jeugdgroepen in de regio Haaglanden voor het eerst een onderscheid maakten naar hinderlijke, overlastgevende, criminele groepen en jeugdbendes. 
eeuwigdurende discussie over de definitie van het gangfenomeen. In met name de rijke Amerikaanse traditie van gangonderzoek is er jarenlang discussie gevoerd over de definitie van dit fenomeen, inclusief het al dan niet includeren van criminaliteit in de definitie (zie bijvoorbeeld Ball \& Curry, 1995; Short, 1968; Klein, 1995, 23-29). Het ziet ernaar uit dat de discussie hierover nog zal blijven voortduren, ook na de ontwikkeling van de Eurogang-consensusdefinitie (zie bijvoorbeeld Esbensen \& Maxson, 2011; Fraser \& Hagedorn, 2016).

\section{Veranderende grenzen en verschijningsvormen van criminele groepen}

Een aantal recente ontwikkelingen laten zien dat de grenzen tussen verschillende criminele groepen minder duidelijk of afgebakend zijn dan door zowel binnen- als buitenstaanders wordt aangegeven. Zo werd in een recente brief over de integrale aanpak van OMCG's aan minister Van der Steur van Veiligheid en Justitie (LIEC, 2016) gewezen op het ontstaan van 'fluïde verbanden' rondom OMCG's. Het verloop tussen en binnen clubs zou merkbaar zijn toegenomen en bovendien eenvoudiger zijn geworden. Daarnaast heeft de populariteit van OMCG's geresulteerd in een toename van het aantal 'supportclubs' en 'supportcrews': clubs die via hun website en kleding laten weten een bepaalde OMCG te steunen, zoals Red Devils, Saudarah en 81 Support Crew. Deze 'steun' kan, aldus het LIEC, bestaan uit het draaien van bardiensten tijdens clubavonden tot het verlenen van criminele hand-en-spandiensten. Leden van supportclubs worden ook ingezet als knokploegen in de onderlinge concurrentiestrijd tussen OMCG's en vormen een kweekvijver voor nieuwe OMCG-leden (Barker, 2017; DLIO, 2017). Een deel van deze supportclubs is zelf ook motorclub, maar bij sommige supportclubs speelt het motorrijden een ondergeschikte, of zelfs helemaal geen rol.

Naast de supportclubs en -crews die een duidelijke link hebben met OMCG's, ziet Nederland zich ook in toenemende mate geconfronteerd met zogenaamde 'brotherhoods' of 'look-a-like clubs', zoals Black Jackets, Catervarius en Brotherhood No Fear. Deze clubs vertonen veel kenmerken van OMCG's - bijvoorbeeld het dragen van clubkleding met een clublogo, top en bottom rocker, een organisatiestructuur met een moederchapter en verschillende lokale (onder)afdelingen, en een met OMCG's vergelijkbare interne organisatie met rangen, zoals president, vice president en sergeant at arms. In deze clubs speelt motorrijden echter geen rol en de clubs zelf benadrukken doorgaans - onder andere in de pers, in andere media, op hun website of op hun socialmedia-accounts - dat zij geen motorclub zijn. In Australië staat een vergelijkbaar fenomeen bekend als 'Nike Bikies' (Lauchs, 2017).

In de eerdergenoemde brief wordt ook gesproken over het bestaan van relaties tussen OMCG's en 'street gangs' (LIEC, 2016, 2). Op basis van etnografisch onderzoek naar de Rollin 200 Crips beschrijft Roks (2016) zulke relaties en criminele contacten tussen leden van deze Haagse 'gang' en outlawbikers van Satudarah en No Surrender. Zo waren er voormalige leden van de Crips die aansluiting zochten bij een van deze OMCG's, maar vielen er ook omgekeerde bewegingen waar te nemen. De in augustus 2012 om het leven gebrachte Quincy Soetosenojo 
maakte onderdeel uit van zowel de Haagse als de Amsterdamse tak van de Crips en was tevens aspirant-lid van Satudarah (Roks, 2017c). Een deel van deze Amsterdamse Crips zocht vervolgens aansluiting bij een OMCG (Van Gemert e.a., 2016, 167-169). Anno 2017 gaat een deel van de Haagse Rollin 200 Crips na een fusie met een chapter van OMCG Trailer Trash MC door het leven als Caloh Wagoh Main Triad MC, een hybride 'gang' met (stijl)kenmerken van zowel een straatbende als een OMCG (Roks, 2017a).

Deze voorbeelden illustreren toegenomen complexe verschijningsvormen van de huidige criminele groepen. Er lijkt sprake te zijn van fluïde verbanden tussen criminele groepen, maar ook van het ontstaan van hybride criminele groepen. Hoe moeten we deze verschijningsvormen duiden? Hebben we hier te maken met nieuwe fenomenen, of is er al langer sprake van overlappende relaties en mengvormen tussen verschillende criminele groepen? In hoeverre zijn deze hybride criminele groepen het resultaat van de manier waarop specifieke (jeugd)groepen zich hebben ontwikkeld? Het is de moeite waard om dergelijke vragen in toekomstig onderzoek nader te exploreren. Ook rijst de vraag wat de invloed is van de opkomst van social media en smartphones op de veranderende structuur, dynamiek en mengeling van uitingsstijlen van deze criminele groepen.

\section{Criminele groepen in een gedigitaliseerde wereld}

Internet heeft ons toegang gegeven tot gelijkgestemden over de hele wereld. Websites, Facebook groepen en darknet fora zijn online ontmoetingsplaatsen voor personen met gedeelde interesses, doelen en identiteit. Een van de belangrijkste vragen op dit moment is dan ook in hoeverre onze wetenschappelijke kennis over groepen en criminele groepen in het bijzonder nog steeds geldig is in de online wereld. Een recente studie van Leukfeldt (2016) geeft inzicht in zogenaamde 'cybercriminele' netwerken, waaronder het ontstaan, de groei, de structuur en de modus operandi van dergelijke netwerken. In de meerderheid van de netwerken die de auteur beschrijft, spelen sociale relaties met de offline wereld nog steeds een belangrijke rol. Ten aanzien van meer traditionele criminele groepen, zoals problematische jeugdgroepen, stelt Weerman $(2017,82)$ dat ontwikkelingen op het gebied van ICT en sociale media van groot belang kunnen zijn voor de aanwezigheid op straat. Dergelijke groepen lijken zich niet langer exclusief offline te manifesteren, maar hebben hun activiteiten en criminele gedragingen en uitingen voor een deel verplaatst naar het online domein (Van den Broek, 2013; Roks, 2017b). Weerman (2017, 79) suggereert dat delinquent gedrag op straat in groepsverband voor een deel van de jongeren door de opkomst van sociale media minder nodig is als middel om ergens bij te horen en erkenning te krijgen van anderen, maar dat deze behoeften nu ook (deels) op afstand bevredigd kunnen worden via een smartphone met internetverbinding.

In het buitenland wordt eveneens gesignaleerd dat het internet een verandering heeft teweeggebracht in de manier waarop criminele groepen zoals gangs zich presenteren en met elkaar interacteren (Storrod \& Densley, 2017, 680-681). Pyrooz e.a. (2015) menen zelfs dat het internet de criminele en routineactivitei- 
ten van gangleden heeft geherdefinieerd. Gangleden lijken het internet en sociale media net zo vaak, zo niet vaker te gebruiken dan leeftijdgenoten die geen onderdeel uitmaken van een gang. De auteurs signaleren dat het internet door deze gangleden zelden ingezet wordt voor instrumentele doelen, maar veelal in dienst staat van de symbolische behoeften van gangleden. Lauger en Densley (2017) komen op basis van een analyse van rapvideo's van gangleden op YouTube tot een vergelijkbare conclusie. De auteurs stellen dat het online domein fungeert als een virtuele straathoek, waarbij gangleden hun bereidheid en betrokkenheid bij het plegen van zware vormen van geweld benadrukken en op tijden lijken te overdrijven. Dit draagt bij aan de mythevorming van hun criminele groep, maar vormt eveneens een manier om zowel hun individuele als hun collectieve identiteiten vorm te geven en te presenteren.

Ook extremistische bewegingen maken gretig gebruik van de mogelijkheden die de gedigitaliseerde wereld hun biedt (Weimann, 2005). Het internet, maar sociale media in het bijzonder, heeft een fundamentele verandering teweeggebracht in de communicatie van dergelijke criminele groepen. Terroristen zijn hierbij niet langer afhankelijk van de mainstreammedia. Het verspreiden van informatie over achtergronden en doelen van de terroristische organisatie gebeurt nu via websites met daarop beschrijvingen van de geschiedenis van de groepering en gezichtsbepalende figuren, maar ook van de politieke en ideologische doelen. Internet'glossy' Dabiq lijkt ook een dergelijke propagandafunctie te vervullen (Wilbur, 2017). Klausen (2015) wijst daarnaast op de rol die Twitter heeft gespeeld in het rekruteren en indoctrineren van sympathisanten voor de gewapende strijd van IS in Syrië en Irak. Naast communicatiemiddel, stellen social media jihadinetwerken ook in staat om een transnationale gemeenschap van gewelddadig extremisme op te bouwen.

\section{Inhoud themanummer}

Het eerste artikel in dit themanummer richt zich op de grenzen van een groep. Wolters, Oosterhuis en Dijkstra onderzoeken op basis van politieregistraties de sociale relaties van en tussen personen die door de politie worden aangemerkt als lid van een problematische jeugdgroep. Een sociale netwerkanalyse levert een formeel beeld op van zowel de criminele jeugdgroep als het omliggende sociale netwerk. Het artikel richt zich op het beantwoorden van de vraag in hoeverre dit formele beeld overeenkomt met het beeld dat politie zich in de praktijk van deze jeugdgroep heeft gevormd. De resultaten van de analyse bieden politie en justitie handvatten voor het gericht aanpakken van individuele personen en groepen binnen het bredere sociale netwerk.

Het tweede artikel van Van Gestel geeft zicht op de wereld van groepen rondtrekkende daders die zich op georganiseerde wijze schuldig maken aan (voornamelijk) vermogensmisdrijven. De auteur schetst op basis van vijftien strafrechtelijke opsporingsonderzoeken een beeld van de manier waarop deze mobiele bendes te werk gaan, maar vooral hoe leden van dergelijke mobiele bendes hun criminele activiteiten en groepslidmaatschap definiëren en beleven. Het artikel toont aan 
hoe deze groepsbeleving is ingebed in een grotere, internationale subcultuur van personen die criminaliteit zien als werk.

Het artikel van Koetsenruijter en Burger richt zich op de beeldvorming die er over outlawbikers bestaat. Waar politie en justitie baat hebben bij het neerzetten van outlaw motorclubs als 'criminele groepen', is het belang van de motorclubs om zich te presenteren als mannen met een reguliere hobby. De auteurs beschrijven op basis van een kwalitatieve framinganalyse de manier waarop outlaw motorclubs proberen hun duale imago in de Nederlandse geschreven pers te onderbouwen.

De twee laatste artikelen in dit themanummer gaan over 'harde-kernsupporters', groepen die hun identiteit in de eerste plaats ontlenen aan een betaaldvoetbalclub, maar in de tweede plaats ook aan hun relatie tot harde-kernsupportersgroepen van andere voetbalclubs. Het artikel van Van Ham illustreert hoe harde-kernsupporters hun groepsidentiteit vormgeven en tot uiting brengen door het organiseren van zogenaamde 'vechtafspraken'. Deze gewelddadige confrontaties blijken in hoge mate geritualiseerd. De auteur beschrijft de achtergronden van dit relatief onbekende fenomeen, wat er bekend is over de deelnemers aan vechtafspraken en hun motieven om deel te nemen aan deze geritualiseerde gewelddadige confrontaties.

Collard en Kleemans ten slotte beschrijven op basis van twaalf opsporingsonderzoeken de wijze waarop groepslidmaatschap van de harde kern van een Nederlandse betaaldvoetbalclub een rol kan spelen bij een vorm van criminaliteit die minder snel met hooliganisme wordt geassocieerd: (grensoverschrijdende) drugshandel. Lidmaatschap van de harde kern voorziet in dezen in twee behoeften die daders van georganiseerde misdaad hebben: een basis voor onderling vertrouwen en de gelegenheid vrijwel ongezien (en daarmee ongestraft) hun delicten te plegen. De auteurs laten zien dat de criminele groep harde-kernsupporters dankbaar gebruik maakt van de sociale en fysieke gelegenheid die medesupporters (in binnen- en buitenland) en supportersfaciliteiten, zoals voor niet-leden ontoegankelijke supportershomes, bieden.

\section{Toekomstig onderzoek}

Anno 2017 is de mens nog altijd een sociaal wezen. Ook daders zijn mensen en in veel van hun delictgedrag spelen andere mensen daarom direct of indirect een rol. Niet alleen zoeken daders andere daders op om kennis te krijgen van de vaardigheden en gelegenheden die nodig zijn voor het plegen van hun delicten, samenwerking creëert soms ook die gelegenheid. Anderzijds voorziet lidmaatschap of identificatie met een bepaalde groep ook in minder tastbare menselijke behoeften, bijvoorbeeld als een kapstok voor de eigen identiteit en het gevoel ergens bij te horen. Niet de materiële voordelen van groepslidmaatschap, maar juist de immateriële betekenis van de groep - voor leden en niet-leden - is hier van belang. Wanneer criminaliteit een belangrijk onderdeel is van de groepsidentiteit, of de reputatie en mythevorming rond de groep worden ingezet voor het creëren 
van criminele gelegenheden, dan kan groepslidmaatschap ook via deze weg de kans op crimineel gedrag van haar leden vergroten.

Crime-scriptanalyse en sociale netwerkanalyse zijn aangewezen methoden om verschillende (samenwerkings)verbanden in kaart te brengen en te begrijpen. Met name die laatste methode staat binnen de Nederlandse criminologie nog in de kinderschoenen. Toekomstig Nederlands onderzoek zou zich op basis van gegevens over samenplegen - onder andere uit politieregistraties en -dossiers - kunnen richten op de aard en omvang van criminele netwerken en het identificeren van cliques en key players binnen deze netwerken. Om zicht te krijgen op de evolutie van criminele groepen over de tijd en de gevoeligheid van dergelijke groepen voor interventies van buitenaf zouden longitudinale netwerkanalyses geschikt zijn. Daarnaast zouden toekomstige sociale netwerkanalyses van criminele groepen zich kunnen richten op het inzichtelijk maken van de samenwerking tussen (leden van) verschillende criminele groepen.

Deze methoden geven echter weinig zicht op de immateriële behoeften waarin groepslidmaatschap van een criminele groep kan voorzien. Politiedossiers kunnen tot op zekere hoogte worden gebruikt om de betekenisgeving van het groepslidmaatschap door leden en niet-leden te achterhalen, met de kanttekening dat de informatie die hiervoor nodig is doorgaans beperkt blijft tot 'bijvangst' uit bijvoorbeeld tap- en verhoorverslagen. Voor het achterhalen van de betekenis die daders aan hun groepslidmaatschap hechten en op welke wijze deze betekenisgeving samenhangt met de door hen gepleegde delicten, is ook onderzoek nodig dat nog dichter op de huid van de betrokken personen kruipt en groepsleden zelf aan het woord laat, zonder de vertaalslag van politie en justitie die inherent is aan officiële gegevens. Etnografisch onderzoek werd, met enkele belangrijke uitzonderingen, in Nederland vooral verricht onder jeugdgroepen, maar een dergelijke onderzoeksbenadering onder andere typen groepen - zoals bijvoorbeeld hooligans, outlawbikers of mobiele bandieten - kan eveneens waardevolle perspectieven opleveren. De grote rol die sociale media in het alledaagse leven zijn gaan spelen en de expliciete manifestatie van criminele groepen op het internet maken dat onderzoekers zich daarbij ook zullen moeten richten op zowel de virtuele straathoek als de aantrekkingskracht van bredere bewegingen die, ongeacht fysieke afstand, een belangrijke invloed kunnen hebben op het gedrag van personen die zich met deze criminele groepen identificeren.

\section{Literatuur}

Ball, R.A. \& Curry, G.D. (1995). The logic of definition in criminology: purposes and methods for defining 'gangs'. Criminology, 33(2), 225-245.

Barker, T. (2014). Biker gangs and transnational organized crime. London: Routledge.

Barker, T. (2017). Motorcycle clubs or criminal gangs on wheels? In: A. Bain \& M. Lauchs (eds.). Understanding the outlaw motorcycle gangs: international perspectives. Durham: Carolina Academic Press, 7-28.

Beke, B.M.W.A., Wijk, A.Ph. van \& Ferwerda, H.B. (2000). Jeugdcriminaliteit in groepsverband ontrafeld. Tussen rondhangen en bendevorming. Amsterdam: Uitgeverij SWP. 
Bie, J.L.D. de (2016). How jihadist networks operate: a grounded understanding of changing organizational structures, activities, and involvement mechanisms of jihadist networks in the Netherlands. Instituut voor Strafrecht en Criminologie, Faculteit Rechtsgeleerdheid, Universiteit Leiden.

Blokland, A.A.J., Soudijn, M.R.J \& Leest, W. van der (2017). Outlaw bikers in the Netherlands: clubs, social criminal organizations, or gangs. In: A. Bain \& M. Lauchs (eds.). Understanding the outlaw motorcycle gangs: international perspectives. Durham: Carolina Academic Press, 91-114.

Broek, J.B.A. van den (2013). Van de straathoek naar Facebook. Een onderzoek naar het gebruik van social media door jongeren binnen de straatcultuur. Ongepubliceerde masterscriptie. Erasmus Universiteit Rotterdam.

Bruinsma, G. \& Bernasco, W. (2004). Criminal groups and transnational illegal markets. Crime, Law and Social Change, 41(1), 79-94.

DLIO (2017). Outlaw gangs in Nederland. OMG-signaal document, mei 2017.

Esbensen, F.A. \& Maxson, C.L. (eds.) (2011). Youth gangs in international perspective: results from the Eurogang program of research. New York: Springer Science \& Business Media.

Ferwerda, H. \& Ham, T. van (2015). Problematische jeugdgroepen in Nederland. Omvang en aard in het najaar van 2014. Arnhem: Bureau Beke.

Ferwerda, H. \& Ham, T. van (2017). Lessen uit de aanpak van jeugdgroepen. Justitiële verkenningen, 43(6), 112-126.

Ferwerda, H. \& Wijk, A. van (2015). Groepsscan vormt nieuwe basis aanpak jeugdgroepen. Secondant, 14 december.

Fraser, A. \& Hagedorn, J.M. (2016). Gangs and a global sociological imagination. Theoretical Criminology. doi: 10.1177/1362480616659129.

Gemert, F.H.M. van (1995). Gangs in Amerika en Nederland. Grimmige realiteit versus modeverschijnsel. Justitiële verkenningen, 21(9), 68-83.

Gemert, F.H.M. van (1998). Crips in drievoud. Een dossieronderzoek naar drie jeugdbendes. Amsterdam: Regioplan Onderzoek Advies en Informatie.

Gemert, F.H.M. van (2012). Five decades of defining gangs in the Netherlands: the Eurogang paradox in practice. In: F.A. Esbensen \& C.L. Maxson (eds.). Youth gangs in international perspective: results from the Eurogang program of research. New York: Springer, 69-83.

Gemert, F.H.M. van, Peterson, D. \& Lien, I.L. (eds.) (2008). Street gangs, migration and ethnicity. Devon/Portland: Willan Publishing.

Gemert, F.H.M. van, Roks, R.A \& Drogt, M. (2016). Dutch Crips run dry in liquid society. In: C.L. Maxson \& F.A. Esbensen (eds.). Gang transitions and transformations in an international context. New York: Springer International Publishing, 157-172.

Gruter, P., Baas, M. \& Vegter, D. (1996). Problematische jeugdgroepen in de regio Haaglanden. Een inventarisatie onder wijkagenten en jeugdrechercheurs. Den Haag: Politie Haaglanden, Bureau Analyse en Research.

Ham, T. van \& Ferwerda, H. (2017). Duiding van problematisch jeugdgroepgedrag. Een theoretische verkenning en een praktische handreiking voor het veld. Arnhem: Bureau Beke.

Hellemont, E. van (2015). The gang game: the myth and seduction of gangs. Koninklijke Universiteit van Leuven, België.

Klausen, J. (2015). Tweeting the jihad: social media networks of Western foreign fighters in Syria and Iraq. Studies in Conflict \& Terrorism, 38(1), 1-22.

Kleemans, E.R. \& Poot, C.J. de (2008). Criminal careers in organized crime and social opportunity structure. European Journal of Criminology, 5(1), 69-98. 
Kleemans, E.R., Berg, E.A.I.M. van den, Bunt, H.G. van de, Brouwers, M., Kouwenberg, R.F. \& Paulides, G. (1998). Georganiseerde criminaliteit in Nederland. Rapportage op basis van de WODC-monitor. Den Haag: WODC.

Klein, M.W. (1995). The American street gang: its nature, prevalence and control. New York: Oxford University Press.

Landelijke Eenheid Politie (2014). Outlawbikers in Nederland. Woerden: Dienst Landelijke Informatieorganisatie.

Lauchs, M. (2017). Nike Bikies. In: A. Bain \& M. Lauchs (eds.). Understanding the outlaw motorcycle gangs: international perspectives. Durham: Carolina Academic Press, 115-134.

Lauger, T.R. \& Densley, J.A. (2017). Broadcasting badness: violence, identity, and performance in the online gang rap scene. Justice Quarterly. Article first published online. doi.org/10.1080/07418825.2017.1341542.

Laumans, W. \& Schrijver, M. (2014). Mocro maffia. Geld, ambitie en verraad in de onderwereld. Amsterdam: Lebowski Publishers.

Leukfeldt, R. (2016). Cybercriminal networks. Origin, growth and criminal capabilities. Den Haag: Eleven International Publishing.

LIEC (Landelijk Informatie en Expertise Centrum) (2016). Brief aan de minister van Veiligheid en Justitie. Voortgang integrale aanpak outlaw motorcycle gangs. Den Haag: LIEC.

Mastrigt, S.B. van (2014). Co-offending and offender attributes. In: G. Bruinsma \& D.L. Weisburd (eds.). Encyclopedia of criminology and criminal justice. New York: Springer, 559-570.

Morselli, C. (2013). Crime and networks. London: Routledge.

Morselli, C. \& Boivin, R. (2017). Introduction to the special issue on Crime and Networks. Social Networks. Article first published online. doi.org/10.1016/j.socnet.2017.08.005.

Papachristos, A.V. (2011). The coming of a networked criminology. In: J. MacDonald (ed.). Measuring crime and criminality: advances in criminological theory, 17. New Brunswick: Transaction Publishers, 101-140.

Pyrooz, D.C., Decker, S.H. \& Moule, Jr., R.K. (2015). Criminal and routine activities in online settings: gangs, offenders, and the Internet. Justice Quarterly, 32(3), 471-499.

Roks, R.A. (2016). In de h200d. Een eigentijdse etnografie over de inbedding van criminaliteit en identiteit. Rotterdam: Erasmus School of Law.

Roks, R.A. (2017a). Crip or die? Gang disengagement in the Netherlands. Journal of Contemporary Ethnography. Article first published online. doi.org/ 10.1177/0891241617725786.

Roks, R.A. (2017b). In the 'h200d': Crips and the intersection between space and identity in the Netherlands. Crime, Media, Culture. Article first published online. doi.org/ 10.1177/1741659017729002.

Roks, R.A. (2017c). Liquidatie van een Solid Soldier? Het 'niet-zeker-weten' en de 'realness' rondom de dood van Sin. Justitiële verkenningen, 43(5), 66-80.

Short, Jr., J.F. (1968). Gang delinquency and delinquent subcultures. New York: Harper \& Row.

Spaaij, R. (2008). 'Je leeft er soms al weken naar toe': vergelijkend onderzoek naar voetbalgerelateerd geweld. Tijdschrift voor Criminologie, 51(4), 337-349.

Storrod, M.L. \& Densley, J.A. (2017). 'Going viral' and 'Going country': the expressive and instrumental activities of street gangs on social media. Journal of Youth Studies, 20(6), 677-696.

Weerman, F.M. (2001). Samenplegen: over criminele samenwerking en groepsvorming. Nijmegen: Ars Aequi Libri. 
Weerman, F.M. (2017). Social media en smartphones als verklaring voor de daling in jeugdcriminaliteit? Justitiële verkenningen, 43(6), 71-87.

Weerman, F.M. \& Kleemans, E. (2002). Criminele groepen en samenwerkingsverbanden. Een overzicht. Tijdschrift voor Criminologie, 44(2), 114-127.

Weerman, F.M., Maxson, C., Esbensen, F.-A., Aldridge, J., Gemert F. van \& Medina, J. (2009). Eurogang Program Manual. Background, development and use of the Eurogang tools in multisite multimethod comparitive research. https://www.umsl.edu/ccj/ Eurogang/EurogangManual.pdf

Weimann, G. (2005). The theater of terror: the psychology of terrorism and the mass media. Journal of Aggression, Maltreatment \& Trauma, 9(3-4), 379-390.

Wilbur, D. (2017). Propaganda's place in strategic communication: the case of ISIL's Dabiq Magazine. International Journal of Strategic Communication. Article first published online. doi.org/10.1080/1553118X.2017.1317636. 